\title{
Pendampingan Penulisan Artikel Ilmiah Bagi Guru Matematika Sekolah Menengah Pertama Wilayah Sukaraja Kabupaten Tasikmalaya
}

\author{
Mega Nur Prabawati ${ }^{1}$, Siska Ryane Muslim² \\ FKIP Universitas Siliwangi \\ meganurprabawati@unsil.ac.id, 081221801414 \\ siskaryanemuslim@unsil.ac.id, 08112002728
}

\begin{abstract}
ABSTRAK
Kemampuan menulis bagi guru menjadi tuntutan profesinya. Bagi pengembangan karirnya guru wajib memenuhi syarat berupa penulisan artikel atau karya ilmiah. Syarat ini seringkali menjadi hambatan kenaikan jenjang pangkat bagi guru mengingat rendahnya kemampuan dan minat menulis di kalangan mereka. Kegiatan yang akan dilaksanakan dalam Iptek bagi bina masyarakat ini adalah pendampingan penulisan artikel ilmiah. Tujuan kegiatan ini adalah untuk membantu meningkatkan pemahaman guru Matematika SMP di wilayah Sukaraja kabupaten Tasikmalaya tentang jenis- jenis karya ilmiah, kaidah menulis karya ilmiah, dan menulis artikel secara profesional. Peserta kegiatan IbBM Pendampingan penulisan artikel ilmiah ini adalah Guru matematika yang berada di wilayah Sukaraja kabupaten Tasikmalaya. Metode kegiatan yang dilaksanakan guna menyelesaikan permasalahan mitra adalah dengan pendekatan secara klasikal dan individual. Luaran yang diharapkan dari kegiatan IbBM pendampingan penulisan artikel ilmiah ini adalah berupa artikel ilmiah atau jurnal hasil penelitian guru selama melakukan pembelajaran di sekolah masing-masing. Hasil dan simpulan kegiatan pendampingan ini mencakup beberapa komponen, yaitu: (1) kemauan peserta dalam menulis artikel atau karya tulis ilmiah adalah cukup tinggi; (2) pemahaman peserta terhadap menulis artikel adalah kurang; dan (3) pemahaman peserta terhadap jenis tulisan adalah kurang. Permasalahan yang dialami oleh guru dalam menulis karya ilmiah diklasifikasikan menjadi dua, yaitu masalah eksternal dan masalah internal.
\end{abstract}

Kata Kunci: Artikel Ilmiah, Guru Matematika

\begin{abstract}
The ability to write to the teacher becomes the demands of his profession. For the development of his career the teacher must meet the requirements in the form of writing articles or scientific work. This requirement is often an obstacle to the promotion of the rank for teachers given the low ability and interest in writing among them. The activity that will be carried out in science and technology for community development is assistance in writing scientific articles. The first phase of this activity participants get material related to writing scientific articles. Furthermore, in the second stage, participants of the IbBM activities are required to make scientific articles using mentoring, participatory, and guided methods. The third stage of the participant submits the assignment of scientific articles followed by a discussion involving all the committee members of the IbBM service and training participants. Participants in the IbBM assistance in writing this scientific article are Mathematics teachers in the Sukaraja area of Tasikmalaya district. The expected outputs from the IbBM activities in assisting in writing this scientific article are in the form of scientific articles or journals of the teacher's research results while studying in each school.
\end{abstract}

Keyword: Scientific Articles, Mathematics Teacher 


\section{PENDAHULUAN}

Kemampuan menulis bagi guru menjadi tuntutan profesinya. Bagi pengembangan karirnya guru wajib memenuhi syarat berupa penulisan karya ilmiah. Syarat ini seringkali menjadi penghambat kenaikan jenjang pangkat bagi guru mengingat rendahnya kemampuan dan minat menulis di kalangan mereka. Selain menjadi syarat bagi pengembangan karir, menulis juga menjadi sarana bagi pengembangan diri seorang guru. Guru memiliki banyak potensi dan potensi yang dimilikinya akan berkembang secara optimal dengan menulis. Hal ini didukung oleh banyaknya kondisi guru yang memperkuat peluang bagi berkembangnya kemampuan menulis. Pertama, guru selalu berinteraksi dengan ilmu pengetahuan yang bisa menjadi bahan untuk menulis. Kedua, guru selalu berinteraksi dengan siswa dalam pembelajaran di kelas yang bisa menjadi sumber tulisan. Ketiga, guru sering berinteraksi dengan dunia pendidikan dan berbagai kebijakannya yang dinamis yang selalu menuntutnya berpikir, mengeluarkan ide-ide inovatifnya. Keempat, banyaknya peluang lomba menulis, baik yang diselenggarakan Dinas Pendidikan maupun Departemen Agama sebagai instansi yang menaunginya. Kelima, media massa menyediakan banyak rubrik pendidikan yang memungkinkan bagi guru untuk mengekspresikan gagasan-gagasan inovatifnya.

Munculnya keluhan tidak bisa menulis di kalangan guru tentu saja bukan tanpa sebab. Secara umum ada beberapa kendala yang bisa ditemukan sehingga membuat tingkat partisipasi menulis di kalangan guru ini rendah. Pertama, rendahnya minat membaca dan minat menulis. Aktivitas menulis tidak bisa dilepaskan dari aktivitas membaca. Selama ini guru lebih banyak disibukkan dengan aktivitas mengajar di kelas sehingga kewajiban membaca untuk pengembangan dirinya menjadi tidak terpenuhi. Kedua, keterbatasan ketersediaan bahan bacaan yang bisa menjadi bahan tulisan. Ketiga, tidak adanya rasa percaya diri dan kurangnya pengalaman untuk menulis. Keempat, ketidakpahaman guru atas bekal-bekal keilmuan untuk bisa terampil menulis. Kelima, rendahnya motivasi untuk menulis.

Berangkat dari kondisi tersebut, kami selaku tim pengabdian merasa perlu untuk menyelenggarakan pelatihan menulis untuk para guru. Lingkup penulisan diarahkan pada penulisan karya ilmiah dengan praktikum membuat penelitian tindakan kelas, mengingat jenis itulah yang diperlukan oleh guru untuk memanfaatkan peluang-peluang seperti yang disebutkan di atas. Berdasarkan latar belakang masalah di atas, dapat dirumuskan permasalahan, antara lain:

1. Guru mengalami kesulitan dalam menentukan tema menarik

2. Guru mengalami kesulitan dalam mengembangkan tema artikel ilmiah

3. Guru memiliki kemampuan yang lemah di dalam metodologi penelitian

4. Guru tidak memahami secara baik teknik penulisan artikel ilmiah

5. Guru tidak memiliki media publikasi untuk mempublikasikan artikel ilmiah.

\section{BAHAN DAN METODE}

Kegiatan yang dilaksanakan adalah kegiatan pengabdian berupa IPTEK bina Bagi Masyarakat berupa pendampingan penulisan artikel ilmiah bagi guru matematika sekolah menengah pertama wilayah sukaraja kabupaten tasikmalaya. Tempat kegiatan IbBM dilaksanakan di SMPN 2 Sukaraja kabupaten Tasikmalaya pada tanggal 19 Juni 2019. Peserta pada kegiatan IbBM ini adalah guru matematika yang 
berada di wilayah Sukaraja Kabupaten Tasikmalaya. Tahap pertama pada kegiatan IbBM ini adalah menjelaskan materi yang berkaitan dengan artikel ilmiah, tahap kedua peserta diwajibkan membuat karya ilmiah dengan menggunakan metode pendampingan partisipatif . Tahap selanjutnya melakukan diskusi yang melibatkan semua panitia dan peserta kegiatan.

\section{HASIL}

Jika mengacu pada pelaksanaan kegiatan pendampingan yang telah dilaksanakan, maka dapat diketahui hasil kegiatan pendampingan ini mencakup beberapa komponen, yaitu: (1) kemauan peserta dalam menulis artikel atau karya tulis ilmiah adalah cukup tinggi; (2) pemahaman peserta terhadap menulis artikel adalah kurang; dan (3) pemahaman peserta terhadap jenis tulisan adalah kurang. Berdasarkan hasil temuan dari kegiatan pendampingan yang telah dilakukan, dapat diketahui bahwa pendampingan ini berjalan dengan lancar dan mencapai tujuan kegiatan. Indikatornya adalah bertambahnya pemahaman guru dalam menulis artikel. Peserta sangat antusias dalam mengikuti kegiatan pendampingan penulisan artikel ini. Hal ini dapat diketahui dari banyaknya pertanyaan yang diajukan oleh peserta pada saat kegiatan pendampingan.

Beberapa pertanyaan yang muncul pada saat sesi pemaparan materi dari narasumber adalah: (1) perbedaan artikel hasil riset dengan artikel setara hasil penelitian atau kajian gagasan; (2) perbedaan artikel ilmiah dengan artikel populer; (3) cara menyusun judul penelitian yang menarik; (4) cara menulis abstrak; (5) cara menulis pendahuluan dan metode dalam artikel; (6) cara menulis pembahasan dalam artikel; (7) proses mengirim artikel ke jurnal ilmiah; dan (8) cara menyikapi pengelola jurnal ketika tak kunjung ada kabar artikel yang akan diterbitkan. Guru pada dasarnya memiliki keinginan yang kuat untuk menulis, namun ada permasalahan yang mengganjal guru dalam menulis

\section{PEMBAHASAN}

Menulis, baik menulis karya ilmiah ataupun menulis karya tulis populer adalah pekerjaan yang paling terbuka antara berbagai macam profesi yang ada (Suandi, 2008). Siapapun dapat menulis, namun yang akan membedakan adalah tingkat kedalaman dan keluasan dari tulisan yang dihasilkan. Guru merupakan profesi yang tidak terlepas dari kegiatan menulis, seperti menulis rencana pembelajaran, dari program tahunan, program semester, silabus, rencana pelaksanaan pembelajaran, dan instrumen evaluasi belajar siswa sampai dengan menganalisis hasil belajar siswa.

Menjadi permasalahan tersendiri ketika ada tuntutan guru harus memiliki karya ilmiah pada saat akan mengajukan kenaikan pangkat, yang sesuai dengan amanat Peraturan Menteri Negara Pendayagunaan Aparatur Negara dan Reformasi Birokrasi Nomor 16 Tahun 2009 tentang Jabatan Fungsional Guru dan Angka Kreditnya. Hal itu merupakan harapan bahwa guru merupakan profesi 
yang bersifat keilmuan. Namun pada kenyataannya, kemampuan guru dalam menulis karya ilmiah masih lemah. Lemahnya kemampuan menulis ilmiah para guru antara lain akibat dari keterbatasan mengakses informasi dan juga penguasaan metode ilmiah guru masih terbatas (Kompas, 2010).

Hasil penelitian Larasati (2014) juga menunjukkan bahwa faktor-faktor penghambat penulisan karya tulis ilmiah guru adalah: (1) terbatasnya waktu yang disebabkan oleh tuntutan administratif guru, beban tugas mengajar, dan kesibukan pribadi; (2) gagasan penulisan karya tulis ilmiah tidak berkembang, karena tidak adanya pembimbing dan terbatasnya referensi; dan (3) faktor terbatasnya wawasan tentang menulis karya ilmiah, karena sosialisasi oleh pihak terkait belum optimal. Guru selain menulis karya tulis ilmiah, dapat melakukan pengembangan dengan menyusun tulisan berupa: buku pelajaran dicetak oleh penerbit dan ada International Standard Book Number (ISBN); buku pelajaran dicetak tetapi belum ISBN; dan/atau mengajukan paten sebuah produk atau prototipe yang dihasilkannya (Supriyanto, 2015). Lemahnya kemampuan menulis guru akan berdampak pada kurang baiknya kualitas pembelajaran yang dilaksanakan guru, sebab kegiatan pembelajaran merupakan kegiatan ilmiah yang harus berlandaskan pada kaidah ilmiah juga.

Jika mengacu pada permasalahan guru dalam menulis karya ilmiah maka kunci menyelesaikan masalah tersebut adalah dari diri guru sendiri. Lemahnya budaya menulis juga linier dengan lemahnya budaya membaca. Oleh sebab itu, untuk menulis karya tulis ilmiah, seorang guru juga harus memiliki budaya baca yang tinggi pula. Minat baca rendah guru merupakan salah satu masalah utama pada aspek kompetensi pedagogis guru (Wibowo, 2015). Membaca adalah sebuah cara untuk memasukkan dan memperkaya panduan kosa kata ke dalam diri seorang guru, sehingga dengan membaca banyak referensi yang beragam, akan membuat orang memiliki kekayaan kosakata yang kian beragam pula (Supanti, 2017). Akan lebih menunjang lagi dalam menulis apalagi bila setelah membaca, membuat sebuah catatan-catatan yang merupakan hasil dari membaca tersebut, sehingga kegiatan menulis akan terasa lancar dan catatan yang dimiliki lama kelamaan dapat selengkap dokumen.

Guna menyelesaikan solusi keterbatasan referensi, guru dapat memanfaatkan referensi yang tersedia secara online. Sumber referensi yang dapat diakses secara open source adalah: http://journal.um.ac.id/home/;www.atlantispress.com;www.en.bookfi.net;www.sciencedirect.com; dan https://scholar.google.co.id/. Segala permasalahan yang menghambat guru dalam menulis karya tulis ilmiah merupakan sebuah refleksi dibutuhkannya motivasi dan komitmen yang tinggi untuk menulis dikalangan guru (Djariyo, dkk., 2016). Guru selalu membayangkan betapa rumitnya menemukan sebuah masalah, proses pengambilan datanya, pengolahannya, maupun teknik penulisannya (Fannies, 2016).

Menulis karya ilmiah dapat meningkatkan kompetensi guru khususnya yang menyangkut kompetensi pedagogik dan kompetensi profesional (Suandi, 2008). Guna meningkatkan motivasi menulis guru, menurut Isa, dkk., (2016) guru perlu dikenalkan perangkat lunak untuk penulisan karya ilmiah dengan tujuan dapat meningkatkan motivasi menulis guru. Upaya yang dapat dilakukan sekolah 
untuk meningkatkan kemampuan guru menulis karya ilmiah adalah dengan menyelenggarakan: (1) pertemuan ilmiah guru meliputi diskusi panel, seminar, konferensi, simposium, diskusi, academic workshop (lokakarya), dan seminar kolegial; (2) pelatihan tulisan profesional seperti penelitian, jurnal, atau tulisan populer di media massa; dan (3) program hibah penelitian bagi guru (Gunawan, 2015).

\section{KESIMPULAN DAN SARAN}

Berdasarkan pelaksanaan kegiatan pendampingan ini, disimpulkan: (1) kemauan peserta dalam menulis artikel atau karya tulis ilmiah adalah cukup tinggi; (2) pemahaman peserta terhadap menulis artikel adalah kurang; dan (3) pemahaman peserta terhadap jenis tulisan adalah kurang. Hasil FGD menunjukkan permasalahan yang dialami guru dalam menulis karya ilmiah. Permasalahan yang dialami oleh guru dalam menulis karya ilmiah diklasifikasikan menjadi dua, yaitu masalah eksternal dan masalah internal. Masalah eksternal guru dalam menulis karya ilmiah adalah: (1) kurangnya informasi tentang hal-hal berkaitan dengan menulis; (2) sulitnya menemukan tempat bertanya ketika menulis; (3) keterbatasan referensi dalam menulis; dan (4) proses birokrasi (dibatasi satu jenis tulisan, seperti hasil PTK). Masalah internal guru dalam menulis karya ilmiah adalah: (1) lemahnya budaya menulis di kalangan para guru; (2) rendahnya motivasi guru untuk membuat karya tulis artikel ilmiah; (3) sebagian guru memandang proses birokrasi yang selalu mempersulit membuat mereka menyerah sebelum berusaha; dan (4) keterbatasan waktu untuk menulis.

\section{UCAPAN TERIMA KASIH}

Pihak pelaksana kegiatan pengabdian berupa IbBM penulisan artikel ilmiah bagi guru matematika mengucapkan terimakasih kepada Ketua LP2M-PMP UNSIL dan MGMP Guru matematika wilayah Sukaraja Kabupaten Tasikmalaya yang telah memberikan kesempatan untuk melaksanakan kegiatan ini serta kepada semua pihak yang telah membantu sehingga kegiatan ini bisa terlaksana dengan baik.

\section{DAFTAR PUSTAKA}

Gunawan, I. 2014. Metode Penelitian Kualitatif: Teori dan Praktik. Jakarta: PT Bumi Aksara.

Gunawan, I. 2015. Strategi Meningkatkan Kinerja Guru: Apa Program yang Ditawarkan oleh Kepala Sekolah? Prosiding Seminar Nasional Pengembangan Karir Tenaga Pendidik Berbasis Karya Ilmiah, Fakultas Ilmu Pendidikan Universitas Negeri Malang, 23 Agustus, hlm. 305-312.

Huang, J. C. 2017. What do Subject Experts Teach about Writing Research Articles? An Exploratory Study. Journal of English for Academic Purposes, 25: 18-29. http://dx.doi.org/10.1016/j.jeap.2016.10.004.

Karimnia, A. 2013. Writing Research Articles in ENGLISH: Insights from Iranian University Teachers' of TEFL. Akdeniz Language Studies Conference 2012, (Online), Procedia Social and Behavioral Sciences, hlm. 901-914, (http://www.sciencedirect.com), diakses 13 Januari 2017. 
Komara, A. 2017. Menulis Artikel dan Karya Ilmiah, (Online), (http://www.lpmpjateng.go.id/web/index.php/arsip/artikel/174-menulis- artikel-dan-karyailmiah), diakses 12 Januari 2017.

Larasati, R. T. 2014. Faktor-faktor Penghambat Penulisan Karya Tulis Ilmiah dalam Pengembangan Keprofesian Berkelanjutan Guru SDN Lempuyangwangi Yogyakarta. Tesis tidak diterbitkan. Yogyakarta: Universitas Negeri Yogyakarta.

Ortinau, D. J. 2011. Writing and Publishing Important Scientific Articles: A Reviewer's Perspective. Journal of Business Research, 64: 150-156. doi:10.1016/j.jbusres.2010.02.002.

Suandi, I. N. 2008. Gerakan Menulis Karya Ilmiah (Sebuah Upaya Peningkatan Profesionalisme Guru). Jurnal Pendidikan dan Pengajaran UNDIKSHA, 41(1), 510-531.

Supriyanto, A. 2015. Harapan, Kenyataan dan Strategi Peningkatan Kemampuan Guru dalam Penulisan Karya Tulis Ilmiah, (Online), (http://ap.fip.um.ac.id/wpcontent/uploads/2015/04/13 A-Supriyanto-AP.pdf), diakses 2 Mei 2017.

Tarigan, H. G. 2008. Menulis: Sebagai Suatu Keterampilan Berbahasa. Bandung: Angkasa.

Wibowo, C. H. 2015. Problematika Profesi Guru dan Solusinya bagi Peningkatan Kualitas Pendidikan di MTs Negeri Nguntoronadi Kabupaten Wonogiri. Tesis tidak diterbitkan. Surakarta: Pascasarjana Institut Agama Islam Negeri Surakarta.

Yeganeh, M. T., dan Boghayeri, M. 2015. The Frequency and Function of Reporting Verbs in Research Articles Written by Native Persian and English Speakers. $2^{\text {nd }}$ Global Conference on Linguistics and Foreign Language Teaching, LINELT-2014, Dubai-United Arab Emirates, December 11-13, (Online), Procedia - Social and Behavioral Sciences, hlm. 582586, (http://www.sciencedirect.com), diakses 13 Desember 2016. 